\title{
Sex-related differences in the haematological effects of excessive alcohol consumption
}

\author{
DM CHALMERS ${ }^{1},{ }^{*}$ I CHANARIN ${ }^{3}$, S MACDERMOTT $^{2}$, AND AJ LEVI 1 \\ From the ${ }^{1}$ Divisions of Clinical Sciences, ${ }^{2}$ Medical Computing, and ${ }^{3}$ Haematology, Northwick Park \\ Hospital and Clinical Research Centre, Watford Road, Harrow, Middlesex HA1 3UJ, UK
}

SUMMARY Mean corpuscular volume (MCV) was measured at presentation in 320 hospital patients with a history of excessive alcohol consumption. The MCV of the 94 women thought to be actively drinking more than $80 \mathrm{~g}$ /day of alcohol was $101.3 \mathrm{fl}$ compared with $96.7 \mathrm{fl}$ in their male counterparts. Alcohol consumption, age, smoking habits, prevalence of inadequate diet, or serum and red cell folate levels did not differ significantly between men and women. It is suggested that MCV is a better indicator of excessive alcohol consumption in women than in men, and that women are more susceptible to the haematological toxicity of alcohol.

There is increasing evidence to support the clinical impression that women are more susceptible than men to a variety of alcohol-related diseases (Lancet, 1977; Ashley et al., 1977). Several studies have concluded that women appear to develop cirrhosis with or without alcoholic hepatitis after a shorter period of excessive alcohol consumption (Spain, 1945; Wilkinson et al., 1969; Pequignot et al., 1974; Levi and Chalmers, 1978), and Morgan and Sherlock (1977) and Krasner et al. (1977) have found a significantly higher prevalence of severe alcoholic liver disease among their female patients.

The widespread use of electronic cell counters in haematology has confirmed that an increase in mean corpuscular volume (MCV) is frequently found in hospital patients with known excessive alcohol consumption (Wu et al., 1974, 1975; Buffet, 1976; Morin and Porte, 1976; Davidson and Hamilton, 1978). A previous report from this hospital (Wu et al., 1975) was the first to point out that women who drink heavily tend to have higher MCVs than their male counterparts. This might be because women are more susceptible to the haematological toxicity of alcohol, or, alternatively, it could be due to differences in such factors as alcohol consumption or the pattern of drinking between the two sexes. We have therefore attempted to answer some of these questions by studying sex-related differences in a larger group of patients.

*Present address: c/o Chapel Allerton Hospital, Leeds LS7 4RB

Received for publication 2 August 1979

\section{Methods}

We have studied 320 patients with various alcoholrelated problems who presented between January 1971 and April 1978. Two hundred and sixty-two were seen by the gastroenterology unit or other hospital physicians, and the remainder ( 33 men and 25 .women) presented to one consultant psychiatrist over a period of one year. All these patients were thought to have consumed more than $80 \mathrm{~g}$ of alcohol daily for at least one year; the majority were steady rather than 'spree' drinkers, and most were drinking up to the time of presentation. Four other patients with chronic gastrointestinal bleeding were excluded, as were five patients with $B_{12}$ deficiency (usually secondary to previous gastric surgery), and one woman with untreated thyrotoxicosis. Patients were classified as wine/spirit or beer/cider drinkers, depending on which of these groups of beverages provided more than $50 \%$ of their average daily alcohol intake. Details of smoking habit were recorded, and patients' diets were classified as 'adequate' if they regularly ate at least one meal daily.

Blood counts were performed within 24 hours of presentation using a Coulter Counter Model S set so that the haematocrit excluded trapped plasma (England $e$ al., 1972). Serum and red cell folate were measured using Lactobacillus casei as test organism, and serum $\mathbf{B}_{12}$ with Lactobacillus leishmannii. Sternal marrow aspiration was carried out shortly after admission in 138 patients.

Liver function tests were performed using standard laboratory techniques, and serum gammaglutamyl 
transpeptidase (GGTP) was measured in 250 patients by the method of Rosalki et al. (1970). Percutaneous liver biopsy was performed in 210 patients with clinical or biochemical evidence of liver disease, and further details of the mode of presentation and histological findings have been described elsewhere (Levi and Chalmers, 1978).

To obtain comparative values for MCV we also prospectively studied 88 new patients referred to a gastroenterology outpatient clinic (44 men and 44 women), whose average alcohol intake was assessed as being less than $20 \mathrm{~g}$ daily. None of these patients was subsequently diagnosed as having any haematological disorder, gastrointestinal bleeding, or malabsorption.

These studies were approved by the hospital Ethical Committee, and the data were analysed using $2 \times 2 \chi^{2}$ or $t$ tests. As the values for GGTP showed a log normal distribution logarithmic conversion was performed before statistical calculations.

\section{Results}

Of the 320 patients with high alcohol consumption, 218 were men and 102 women, giving a sex ratio of $2 \cdot 14: 1$. Mean corpuscular volumes at presentation of the 301 patients thought to be actively drinking (defined as those drinking regularly until at least two weeks before presentation) are shown in Fig. 1, together with the results from 88 gastroenterology outpatients drinking less than $20 \mathrm{~g} /$ day. The mean MCV of the women 'drinkers' $(101.3 \mathrm{fl}$, standard deviation $8.0 \mathrm{fl}$ ) was significantly higher than in the men $(96.7 \pm 7.2 \mathrm{fl}, \mathrm{P}<0.001)$, and both high alcohol consumption groups had higher MCVs than the gastroenterology outpatients $(P<0.001)$. In the latter group, there was no significant difference between the MCV of the women $(86.4 \pm 3.2 \mathrm{fl})$ and of the men $(86.0 \pm 3 \cdot 1 \mathrm{fl})$.

Thus $94 \%$ of the women actively drinking more than $80 \mathrm{~g} /$ day had MCVs above the upper limit of

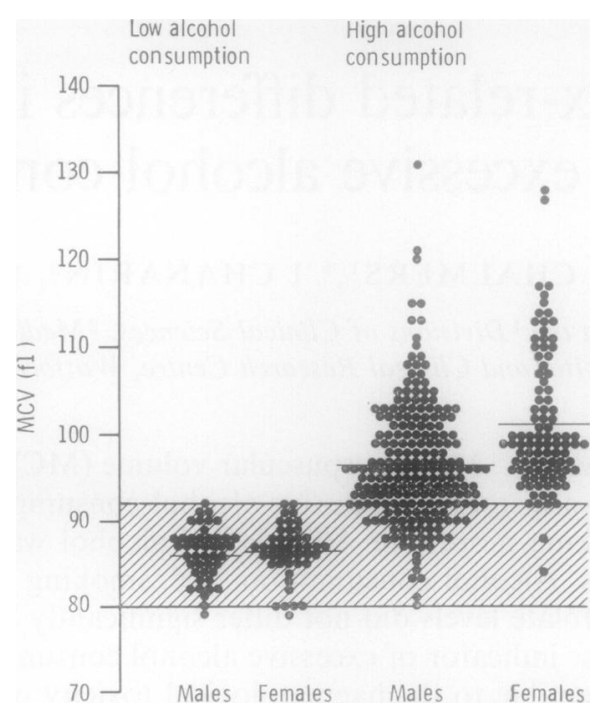

Fig. 1 MCV at presentation of patients actively drinking more than $80 \mathrm{~g} /$ day of alcohol compared with gastroenterology outpatients consuming less than $20 \mathrm{~g} /$ day. The hospital reference range is indicated by the shaded area. Means indicated by bars.

the reference range (80-92 fl) compared with only $71 \%$ of the men. The remaining 19 patients (11 men and 8 women) with a past history of excessive drinking or currently drinking less than $80 \mathrm{~g}$ /day had a mean MCV of $87 \cdot 7 \mathrm{fl}$ (women $85 \cdot 7 \mathrm{fl}$, men $89 \cdot 1$ ).

To determine if the sex difference in MCV in those who were actively drinking could be explained in terms of differences in alcohol consumption, type of beverage, smoking habit, diet, or age, the data were analysed as shown in Table 1. This shows that there was no statistically significant difference in age, prevalence of inadequate diet, or smoking habit between the two groups. Although the men tended to drink larger quantities of alcohol there was no

Table 1 Comparison of 207 men and 94 women actively drinking more than $80 \mathrm{~g} /$ day of alcohol

\begin{tabular}{|c|c|c|c|}
\hline & Men & Women & $\mathbf{P}$ \\
\hline $\begin{array}{l}\text { Mean age (years) } \pm S D \\
\text { Percentage with inadequate diet* } \\
\text { Smoking habit: }\end{array}$ & $\begin{array}{l}50.5 \pm 12.5 \\
21.8\end{array}$ & $\begin{array}{l}52 \cdot 1 \\
29 \cdot 4\end{array}$ & $\begin{array}{l}\text { NS } \\
\text { NS }\end{array}$ \\
\hline $\begin{array}{l}\text { Regular smokers }(\%) \\
\text { Mean no. of cigarettes/day } \pm \text { SD } \\
\text { Percentage of wine/spirit drinkers* } \\
\text { Mean duration of excessive alcohol consumption (years) } \\
\text { Mean present alcohol consumption } \dagger(\mathrm{g} / \mathrm{day} \pm \mathrm{SD}) \text { (number) } \\
(\mathrm{g} / \mathrm{kg} / \text { day } \pm \mathrm{SD}) \text { (number) }\end{array}$ & $\begin{array}{l}78 \cdot 5 \\
18 \cdot 1 \pm 17 \cdot 8 \\
58 \cdot 0 \\
15 \cdot 9 \pm 9 \cdot 0 \\
159 \cdot 1 \pm 64 \cdot 2(182) \\
2 \cdot 2 \pm 1 \cdot 0(120)\end{array}$ & $\begin{aligned} 87 \cdot 5 & \\
16 \cdot 5 & \pm 13 \cdot 2 \\
88 \cdot 3 & \\
8 \cdot 6 & \pm 6 \cdot 0 \\
141 \cdot 8 & \pm 55 \cdot 7(70) \\
2 \cdot 49 & \pm 1 \cdot 3(43)\end{aligned}$ & $\begin{array}{l}\text { NS } \\
\text { NS } \\
<0.001 \\
<0.001 \\
<0.05 \\
\text { NS }\end{array}$ \\
\hline
\end{tabular}

NS = not statistically significant.

* For definitions see text.

†Where sufficiently accurate information was available. 
Table 2 Laboratory investigations at presentation of patients actively drinking more than $80 \mathrm{~g} /$ day of alcohol

\begin{tabular}{|c|c|c|c|c|c|}
\hline & \multicolumn{2}{|l|}{ Men } & \multicolumn{2}{|c|}{ Women } & \\
\hline & No. & $\pm S D$ & No. & $\pm S D$ & \\
\hline $\begin{array}{l}\text { Mean haemoglobin }(\mathrm{g} / \mathrm{dl}) \dagger \\
\text { Mean serum folate }(\mathrm{ng} / \mathrm{ml})(\text { reference range } 2-15) \\
\text { Mean red cell folate }(\mathrm{ng} / \mathrm{ml}) \text { (reference range 145-450) } \\
\text { Mean serum } B_{18}(\mathrm{pg} / \mathrm{ml})(\text { reference range 170-1000) } \\
\text { Bone marrow \% \% maloblastic } \\
\text { GGTP (IU/l) (reference range } 0-50) \\
\text { Liver histology \% with cirrhosis } \pm \text { alcoholic hepatitis }\end{array}$ & $\begin{array}{r}204 \\
169 \\
146 \\
167 \\
87 \\
170 \\
147\end{array}$ & $\begin{array}{c}14 \cdot 8 \pm 1 \cdot 74 \\
7 \cdot 13 \pm 4 \cdot 9 \\
300 \cdot 6 \pm 165 \cdot 6 \\
474 \cdot 5 \pm 357 \cdot 0 \\
28 \cdot 7 \\
193 \cdot 8 \pm 227 \cdot 7 \\
20 \cdot 4\end{array}$ & $\begin{array}{r}91 \\
80 \\
75 \\
80 \\
51 \\
75 \\
63\end{array}$ & $\begin{array}{r}13 \cdot 5 \pm 1 \cdot 85 \\
6 \cdot 05 \pm 4 \cdot 7 \\
267 \cdot 0 \pm 174 \cdot 0 \\
484 \cdot 4 \pm 286 \cdot 3 \\
37 \cdot 3 \\
231 \cdot 8 \pm 259 \cdot 3 \\
25 \cdot 4\end{array}$ & $\begin{array}{l}\overline{\text { NS }} \\
\text { NS } \\
\text { NS } \\
\text { NS } \\
\text { NS* } \\
\text { NS }\end{array}$ \\
\hline
\end{tabular}

NS $=$ not statistically significant.

*After logarithmic conversion.

†Excluding six patients ( 3 men and 3 women) presenting with acute gastrointestinal bleeding.

significant sex difference in consumption when this was calculated on a body weight basis. The most striking differences were that the women had a much shorter duration of excessive alcohol consumption, and the majority drank table wine, fortified wine, vermouth, or spirits rather than beer or cider.

The results of the other laboratory investigations are summarised in Table 2. Most of the patients were not anaemic, and, after excluding six patients with acute gastrointestinal blood loss, only four (4\%) women and seven $(3 \%)$ men had haemoglobin concentrations below $10 \mathrm{~g} / \mathrm{dl}$. The women tended to have lower serum and red cell folate levels, but this was not statistically significant, and the majority of the values fell within the normal range. One-third of the sternal marrow aspirates showed megaloblastic erythropoiesis, and although proportionately more women had megaloblastic changes this was not statistically significant. This was also the case with the increased prevalence of cirrhosis and higher GGTP values in the women.

The prevalence of folate deficiency in our patients and its relationship to MCV can be obtained from Figure 2. This shows that out of 221 patients whose red cell folate was measured, only $12.3 \%$ of the men and $20 \%$ of the women had low red cell folate values (serum $B_{12}$ levels were normal in all these patients). The folate deficient patients had higher mean MCVs, but the majority of non-folate deficient patients were also macrocytic, and there was considerable overlap between the groups. Megaloblastic changes were present in some patients in both the folate deficient and non-folate deficient categories.

As most of the women drank wine and spirits which contain very little folic acid, it was possible that this might prove the explanation of their greater prevalence of macrocytosis. However, Table 3 shows that although wine/spirit drinkers had higher MCVs than beer/cider drinkers, the women wine and spirit drinkers had significantly higher MCVs than their

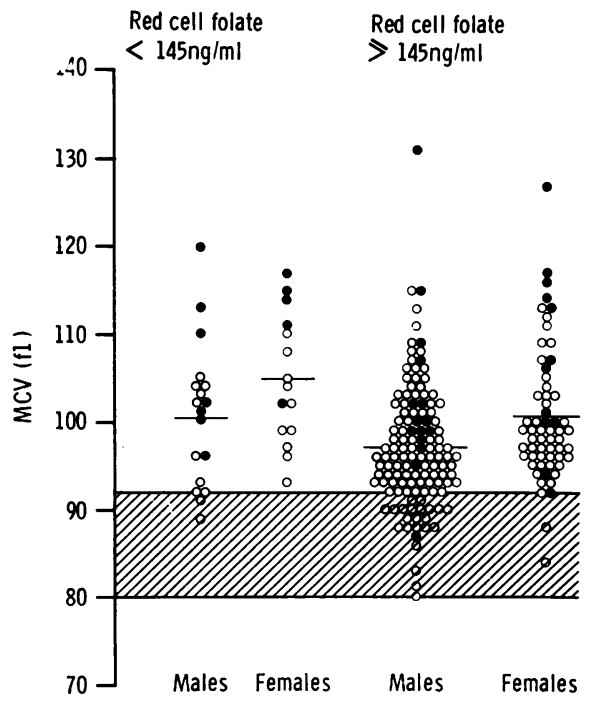

Fig. 2 Distribution of MCV of patients actively drinking more than $80 \mathrm{~g} /$ day of alcohol with normal and low red cell folate levels. The hospital reference range is indicated by the shaded area. Means indicated by bars. Closed circles indicate that megaloblastic bone marrow changes were also present.

male counterparts. The lower MCV of the beer/cider drinkers might have been a result of the higher folate levels, but this group also consumed significantly smaller amounts of alcohol.

\section{Discussion}

An electronic cell counter provides a very accurate and reproducible measure of red cell size. Values of MCV for normal men and women are very similar, and, if anything, women have slightly smaller cells (Kelly and Munan, 1977). Our results show that 
Table 3 Comparison of MCV, folate status, and present alcohol consumption in wine/spirit and beer/cider drinkers

\begin{tabular}{|c|c|c|c|c|}
\hline & \multicolumn{2}{|l|}{ Wine/Spirits } & \multicolumn{2}{|l|}{ Beer/Cider } \\
\hline & Men & Women & Men & Women \\
\hline $\begin{array}{l}\text { Mean } M C V \pm S D(f) \\
\text { Mean serum folate } \pm S D(n g / m l) \\
\text { Mean red cell folate } \pm \text { SD }(\mathrm{ng} / \mathrm{ml}) \\
\text { Mean present alcohol consumption } \pm \mathrm{SD}(\mathrm{g} / \text { day })\end{array}$ & $\begin{array}{r}* 97 \cdot 1 \pm \quad 7 \cdot 4 \\
6 \cdot 2 \pm \quad 4 \cdot 5 \\
272 \cdot 7 \pm 165 \cdot 0 \\
173.9 \pm 66.3\end{array}$ & $\begin{array}{r}* 101 \cdot 9 \pm 8 \cdot 3 \\
5.6 \pm 4 \cdot 4 \\
264 \cdot 6 \pm 177 \cdot 0 \\
148 \cdot 2 \pm 56 \cdot 1\end{array}$ & $\begin{array}{r}96 \cdot 0 \pm \quad 7 \cdot 0 \\
8 \cdot 5 \pm 5 \cdot 2 \\
341 \cdot 1 \pm 161 \cdot 0 \\
140 \cdot 0 \pm 56 \cdot 0\end{array}$ & $\begin{array}{r}97 \cdot 5 \pm \quad 4.9 \\
9 \cdot 3 \pm 5.6 \\
331 \cdot 9 \pm 160 \cdot 0 \\
92 \cdot 5 \pm 10 \cdot 7\end{array}$ \\
\hline
\end{tabular}

*Significant difference $P<0.001$.

women presenting to one district general hospital because of alcohol-related problems tended to have higher MCVs than men with equivalent alcohol intakes. In contrast to the drinking groups, outpatients from the same gastroenterology clinic with low alcohol consumption showed no significant sexrelated differences in MCV, and nearly all the results fell within the reference range.

MCV has been shown to increase slightly with age (Kelly and Munan, 1977) and cigarette smoking (Helman and Rubenstein, 1975), but there was no significant difference in these factors between the men and women drinkers. As it is difficult to obtain accurate drinking histories from alcoholic patients, it is possible that the women might have underestimated their alcohol consumption to a greater extent than the men. However, some corroboration of alcohol intake was obtained from friends or relatives whenever possible, and we think it unlikely that consumption in the women was significantly higher.

In view of the difficulty of recognising excessive alcohol consumption in women it could be argued that we failed to identify women drinkers who were not macrocytic. We felt that this was unlikely to be the case as the sex ratio $(\mathrm{M} / \mathrm{F})$ was only $2 \cdot 1: 1$, which is very similar to recent series of patients with alcoholic liver disease (Morgan and Sherlock, 1977; Krasner et al., 1977) that did not use macrocytosis as an aid to diagnosis. In addition, the sex difference in MCV was also seen in psychiatric patients with alcoholism who did not usually have blood counts performed before referral. We feel that the most likely explanation for our results is that women are more susceptible to the haematological toxicity of excessive alcohol consumption.

The mechanism of these changes remains unclear. Folate deficiency was found in less than $20 \%$ of our patients, and the sex difference in MCV was also found in the non-folate deficient groups. Although our dietary assessments were crude, we are in little doubt that macrocytosis can occur in patients who appear to be taking an adequate diet, and this seems to be due to some direct toxic effect of alcohol on the developing erythroblast. The macrocytosis did not appear to be clearly related to the presence or absence of cirrhosis, and we have found that MCV tends to fall in patients with alcoholic cirrhosis after alcohol withdrawal.

There is relatively little information about possible sex differences in human alcohol metabolism as most studies have been performed on men. However, Reed et al. (1976) found no difference in the calculated rates of alcohol metabolism in normal Caucasian men and women, and mean acetaldehyde concentrations were similar in both sexes. A partial explanation for the susceptibility of women might lie in differences in the volume of distribution of alcohol. Alcohol is distributed in tissues in proportion to their water content, and total body water as a percentage of body weight has been found to be approximately $10 \%$ higher in males (Delwaide and Crenier, 1973). As a result, peak alcohol levels after the same body-weight-adjusted dose tend to be higher in women than in men (Jenkins and Connolly, 1968; Jones and Jones, 1976). It is also of interest that this effect varies at different phases of the menstrual cycle (Jones and Jones, 1976).

Whatever the underlying mechanism, the practical importance of our findings is that a rise in MCV is a better indicator of excessive alcohol consumption in female hospital patients. This makes the MCV particularly useful in detection as these patients are often most reluctant to admit to excessive alcohol consumption (Levi and Chalmers, 1978). Finally, it is our experience that a woman whose MCV is well within the reference range is unlikely to be actively drinking large quantities of alcohol.

We thank the Departments of Clinical Chemistry, Haematology, and Histopathology for measurements and assistance. We also thank Dr H Hershon for permission to study some patients treated under his care. DMC is a Medical Research Council Training Fellow. 


\section{References}

Ashley, M. J., Olin, J. S., Harding Le Riche, W., Kornaczewski, A., Schmidt, W., and Rankin, J. G. (1977). Morbidity in alcoholics. Archives of Internal Medicine, 137, 883-887.

Buffet, C. (1976). L'augmentation du volume globulaire moyen: test de dépistage et de surveillance de l'alcoolisme chronique. Revue de l'Alcoolisme, 22, 15-22.

Davidson, R. J. L., and Hamilton, P. J. (1978). High mean red cell volume: its incidence and significance in routine haematology. Journal of Clinical Pathology, 31, 493-498.

Delwaide, P. A., and Crenier, E. J. (1973). Body potassium as related to lean body mass measured by total water determination and by anthropometric method. Human Biology, 45, 509-526.

England, J. M., Walford, D. M., and Waters, D. A. W. (1972). Re-assessment of the reliability of the haematocrit. British Journal of Haematology, 23, 247-256.

Helman, N., and Rubenstein, L. S. (1975). The effects of age, sex, and smoking on erythrocytes and leukocytes. American Journal of Clinical Pathology, 63, 35-44.

Jenkins, J. S., and Connolly, J. (1968). Adrenocortical response to ethanol in man. British Medical Journal, 2, 804-805.

Jones, B. M., and Jones, M. K. (1976). Alcohol effects in women during the menstrual cycle. Annals of New York Academy of Sciences, 273, 576-587.

Kelly, A., and Munan, L. (1977). Haematologic profile of natural populations: red cell parameters. British Journal of Haematology, 35, 153-160.

Krasner, N., Davis, M., Portmann, B., and Williams, R. (1977). Changing pattern of alcoholic liver disease in Great Britain: relation to sex and signs of autoimmunity. British Medical Journal, 1, 1497-1500.

Lancet (1977). The female alcoholic. Editorial. Lancet, 2, 1015-1016.
Levi, A. J., and Chalmers, D. M. (1978). Recognition of alcoholic liver disease in a district general hospital. Gut, 19, 521-525.

Morgan, M. Y., and Sherlock, S. (1977). Sex-related differences among 100 patients with alcoholic liver disease. British Medical Journal, 1, 939-941.

Morin, J., and Porte, P. (1976). Macrocytose érythrocytaire chez les éthyliques (Letter). Nouvelle Presse Médicale, 5, 273.

Pequignot, G., Chabert, C., Eydoux, H., and Courcoul, M. A. (1974). Augmentation du risque de cirrhose en function de la ration d'alcool. Revue de l'Alcoolisme, 20, 191-202.

Reed, T. E., Kalant, H., Gibbins, R. J., Kapur, B. M., and Rankin, J. G. (1976). Alcohol and acetaldehyde metabolism in Caucasians, Chinese and Amerinds. Canadian Medical Association Journal, 115, 851-855.

Rosalki, S. B., Rau, D., Lehmann, D., and Prentice, M. (1970). Determination of serum gamma-glutamyl transpeptidase activity and its clinical applications. Annuals of Clinical Biochemistry, 7, 143-147.

Spain, D. M. (1945). Portal cirrhosis of the liver: a review of two hundred fifty necropsies with references to sex differences. American Journal of Clinical Pathology, 15, 215-218.

Wilkinson, P., Santamaria, J. N., and Rankin, J. G. (1969). Epidemiology of alcoholic cirrhosis. Australasian Annals of Medicine, 18, 222-226.

Wu, A., Chanarin, I., and Levi, A. J. (1974). Macrocytosis of chronic alcoholism. Lancet, 1, 829-831.

Wu, A., Chanarin, I., Slavin, G., and Levi, A. J. (1975). Folate deficiency in the alcoholic: its relationship to clinical and haematological abnormalities, liver disease and folate stores. British Journal of Haematology, 29, 469-478.

Requests for reprints to: Dr DM Chalmers, Chapel Allerton Hospital, Leeds, Yorkshire LS7 4RB, UK. 